\title{
Fabrication and characterization of LSCF-GDC/GDC/NiO-GDC microtubular SOFCs prepared by multi-dip coating
}

\author{
Tomohiro USUI, Yoichi ITO and Koichi KIKUTA ${ }^{\dagger}$ \\ Department of Crystalline Materials Science, Graduate School of Engineering, Nagoya University, \\ Furo-cho, Chikusa, Nagoya 464-8603
}

\begin{abstract}
Microtubular solid oxide fuel cells were fabricated by the multi-dip coating of ceramic aqueous slurries on steel wire. This is a very convenient way to make small straight tubes without requiring special handling. Prepared NiO-GDC/GDC double layered tubes were separated by dissolving the pre-coated polystyrene layer in organic solvent, then were sintered at $1350^{\circ} \mathrm{C}$. Then a cathode layer of LSCF-GDC was also formed on the double layered tubes with heat treatment at $1100^{\circ} \mathrm{C}$. The prepared microtubular cell performs with a maximum power density of $0.34 \mathrm{~W} / \mathrm{cm}^{2}$ at $550^{\circ} \mathrm{C}$. Microstructure observation of the tubes suggested the possibility of further improvement in cell quality.
\end{abstract}

(c)2010 The Ceramic Society of Japan. All rights reserved.

Key-words : Fuel cell, Microtubular cell, Multi-dip coating, Microstructure control, Electrical Properties

[Received December 8, 2009; Accepted April 15, 2010]

\section{Introduction}

Recently, many types of tubular cells have been investigated for use in electric power systems, hydrogen production, and NOx reduction systems. ${ }^{1-3)}$ Tubular type solid oxide fuel cells have been investigated for more than 15 years due to advantages such as tolerance for rapid thermal cycling and better sealing over planar type cells. ${ }^{4), 5)}$ Recently smaller tubular cells of mm size were intensively studied using $\mathrm{LaGaO}_{3}$, Gd doped ceria, etc. for intermediate temperature operation. Kawakami et al. reported a highly reliable tubular system and Suzuki et al. reported better performance with a high power density over $2 \mathrm{~W} / \mathrm{cm}^{3}$ using microtubular cells. ${ }^{6-8)}$ Our study aimed to make smaller microtubular cells with a diameter less than $1 \mathrm{~mm}$ for a smaller power unit by co-firing, because power density is inversely proportional to tube diameter ${ }^{9), 10)}$ Both anode and cathode supported tubular cells have been fabricated and characterized for future electric power systems. ${ }^{11)-13)}$ Although all of these work adopted the conventional extrusion process for making tubular cells, it is not easy to make large numbers of straight microtubular cells with thinner walls. So, we applied the multi-dip coating using aqueous ceramic slurries with polymer coating using polystyrenes for separation. This pre-coating layer can be removed by dissolution in toluene, so the dried double layer tube can be easily separated from steel wire. This is a preliminary work for the mass production of microtubular cells by the dipping process.

\section{Experimental}

\subsection{Preparation of microtubular cell}

Starting aqueous slurries were prepared by the procedure as shown in Fig. 1. Ceramic powder was first mixed with alkaline aqueous solution with ammonium acrylate-methyl acrylate copolymer (PAM) by ball milling and was mixed with polyvinyl alcohol (PVA) as binder, polyethylene glycol (PEG) as plasticizer, and ammonium oleate as deformer. The composition of the

\footnotetext{
Corresponding author: K. Kikuta; E-mail: kik@apchem.nagoya-u. ac.jp
}

prepared aqueous anode slurries is summarized in Table 1. The binder content in these slurries was changed in order to obtain a homogeneous coating layer on the steel wire. Electrolyte slurries were also prepared to control the thickness of the electrolyte layer by changing GDC powder and PVA binder contents as in Table 2. Microtubular cells can be prepared by simple multi-dip coating using these ceramic slurries based on the experimental flow shown in Fig. 2. Another important step in this procedure is the application of polystyrene coating before slurry coating, which makes it possible to separate the prepared microtubular cell from the steel wire by dissolving polystyrene in toluene.

The prepared tubular cells were set in the platinum boat and were heat treated at $1350^{\circ} \mathrm{C}$ for $4 \mathrm{~h}$. Then, a cathode layer was formed on the tubular cells by the coating of cathode paste prepared from $(\mathrm{La}, \mathrm{Sr})(\mathrm{Co}, \mathrm{Fe}) \mathrm{O}_{3}$ powder (Daiichi Kigenso Kagaku Kogyo Co. Ltd.), ethyl cellose, and telpineol (Kishida Reagents Chemicals). The cells were then heat treated at $1100^{\circ} \mathrm{C}$ for $1 \mathrm{~h}$.

\subsection{Characterization}

The viscosity of the prepared anode and electrolyte slurries was measured using a viscometer (Tokyo Keiki Inc., E-type). The microstructure of the microtubular cells was observed by optical microscopy (Olympus, BX60) and scanning electron microscopy (Jeol, JSM5600). Silver paste was applied on the cathode as a current collector and dried at $100^{\circ} \mathrm{C}$. Cell performance was measured using a Solatron $1255 \mathrm{~B}$ and SI 1287 system as a function of operating temperatures under the gas flow of 20 $\mathrm{ml} / \mathrm{min}$. of humidified hydrogen/nitrogen mixture as an anode gas and $20 \mathrm{ml} / \mathrm{min}$. of air as a cathode gas.

\section{Results and discussions}

\subsection{Preparation of microtubular cells by multi-dip coating process}

The anode layer coating was repeated three times and the shape and homogeneity of the anode layer was observed by an optical microscopy. Figure 3 shows the cross sectional images of the prepared anode cells using a $0.7 \mathrm{~mm}$ steel wire sintered at 


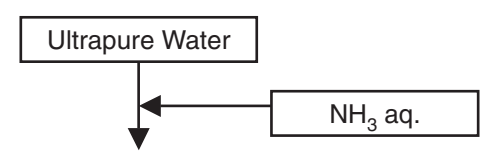

$\mathrm{pH}$ control $\mathrm{pH} 9 \sim 10$

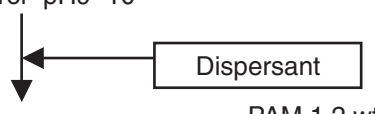

Ball milling $1.5 \mathrm{~h}$

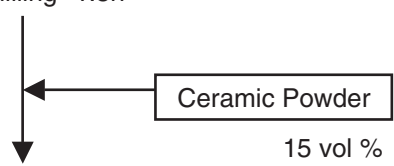

Ball milling $24 \mathrm{~h}$

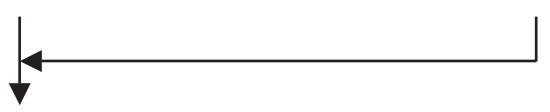

Ball milling $24 \mathrm{~h}$

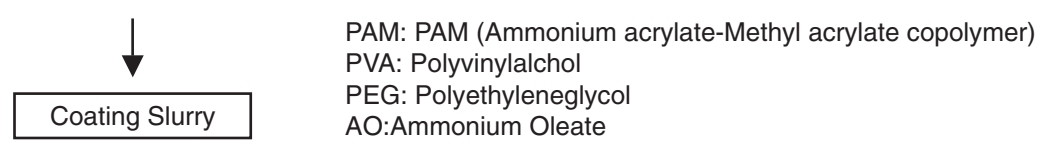

Fig. 1. Experimental flow for the preparation of ceramic slurry.

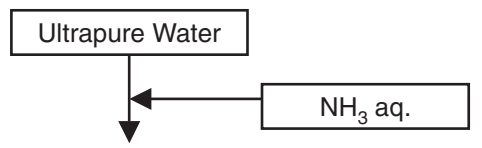

$\mathrm{pH}$ control $\mathrm{pH} 9 \sim 10$

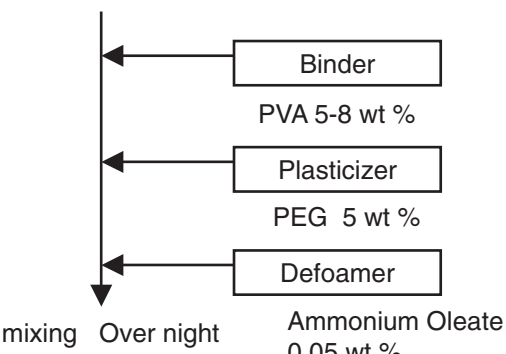

Table 1. Composition of anode slurries

\begin{tabular}{ccc}
\hline Slurry & $\begin{array}{c}\text { NiO/GDC Content } \\
\text { vol \% }\end{array}$ & $\begin{array}{c}\text { Binder* Content } \\
\text { wt \% }\end{array}$ \\
\hline A1 & 15 & 8 \\
A2 & 15 & 6 \\
A3 & 15 & 5 \\
\hline
\end{tabular}

*Binder: PVA (Polyvinyl alcohol)

Plasticizer: PEG (Polyethylene glycol, MW 400), $5 \mathrm{wt} \%$

Dispersant: PAM (Ammonium acrylate-Methyl acrylatecopolymer), $1.2 \mathrm{wt} \%$

Deformer: Ammonium oleate, $0.05 \mathrm{wt} \%$

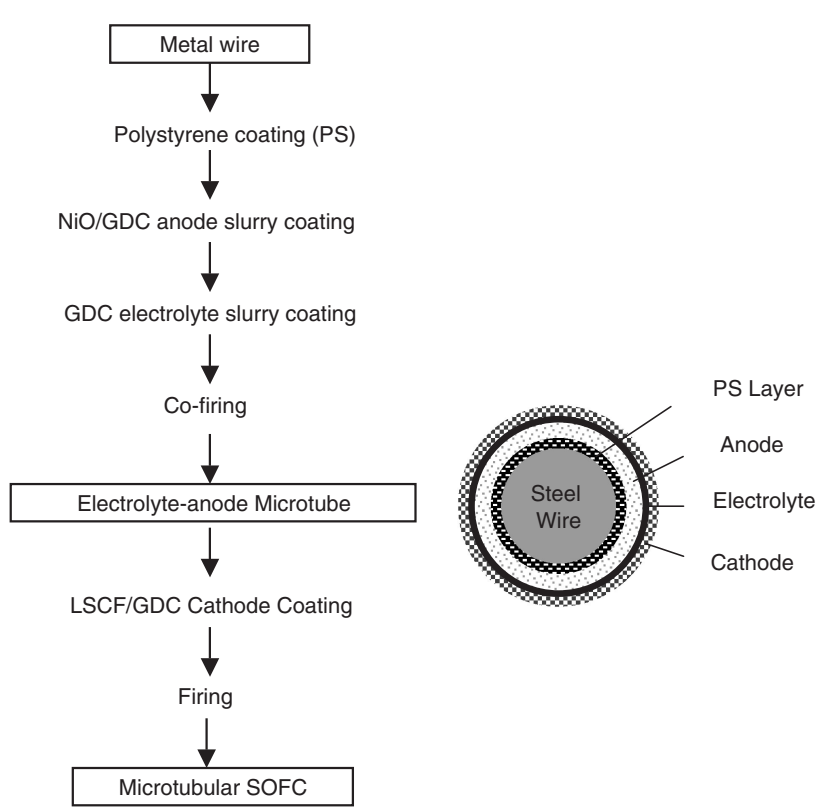

Fig. 2. Preparation of microtubular cell by multi-dip coating.

Table 2. Composition of electrolyte slurries

\begin{tabular}{ccc}
\hline Slurry & $\begin{array}{c}\text { GDC Content } \\
\text { vol } \%\end{array}$ & $\begin{array}{c}\text { Binder* Content } \\
\text { wt \% }\end{array}$ \\
\hline E1 & 17.5 & 5 \\
E2 & 12.5 & 8 \\
E3 & 10 & 8 \\
\hline
\end{tabular}

*Binder: PVA (Polyvinyl alcohol)

Plasticizer: PEG (Polyethylene glycol, MW 400), 5 wt \%

Dispersant: PAM (Ammonium acrylate-Methyl acrylatecopolymer), $0.3 \mathrm{wt} \%$

Deformer: Ammonium oleate, $0.05 \mathrm{wt} \%$

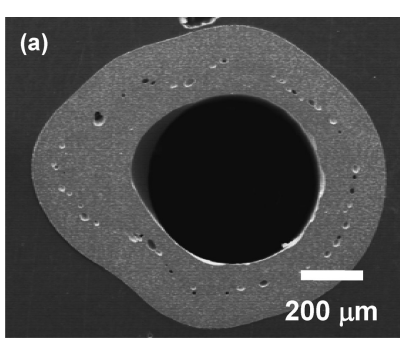

Slurry A1 (2490 mPa·s)

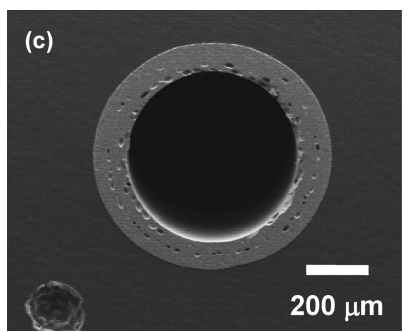

Slurry A3 (250 mPa.s)

Fig. 3. Cross section of anode tubes prepared by multi-dip coating

(three times) and heating at $1350^{\circ} \mathrm{C}$ for $4 \mathrm{~h}$.

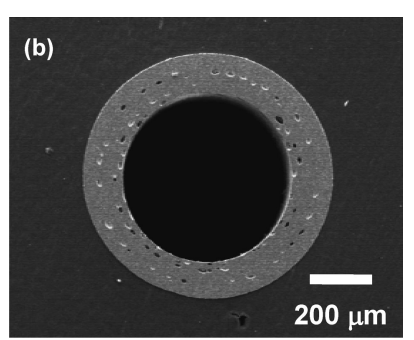

Slurry A2 (470 mPa.s) 


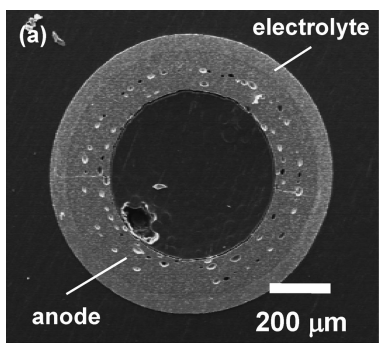

Slurry E1 (1160 mPa.s)

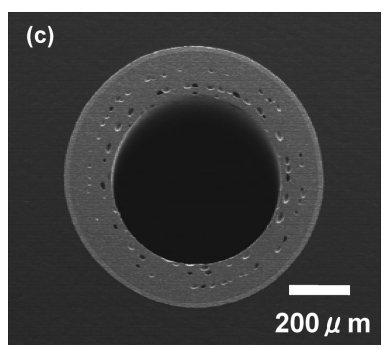

Slurry E3 (360 mPa.s)

Fig. 4. Cross section of anode-electrolyte tubes prepared by multi-dip coating of each slurry and heating at $1350^{\circ} \mathrm{C}$ for $4 \mathrm{~h}$.

$1350^{\circ} \mathrm{C}$. The anode layer prepared by the coating of slurry A1 is very thick and inhomogeneous compared to the other two samples from A2 and A3, because the viscosity of A1 is very high at $2490 \mathrm{mPas}$. The interface of each anode layer can be observed as a dotted circle line composed of small pores existing among the layers, which reveals that the first coating layer on PS layer is thinner than the later coating layers probably because of the weaker chemical affinity between the polystyrene layer and aqueous anode slurry. It was confirmed that A2 and A3 slurries can be used for the preparation of a homogeneous anode layer. In the following experiments, anode coating was carried out to obtain a homogeneous layer with good electric conduction and mechanical strength by repeating the dip coating of slurry A2 with a viscosity of $470 \mathrm{mPas}$ It might be possible to make a layered anode with different compositions and microstructures if necessary for the improvement of cell performance.

Figure 4 shows a prepared anode-electrolyte double layered tube with an outer diameter of $0.96 \mathrm{~mm}$. The electrolyte layer coating was carried out using slurries of E1-E3, suggesting that a homogeneous layer was successfully formed on the anode layer and its thickness can be controlled by changing the viscosity of slurries. The thickness of electrolyte layer E3 is confirmed to be around $20 \mu \mathrm{m}$ after firing as shown in Fig. 4(d).

An advantage of this process is good linearity along with tube length as can be seen in Fig. 5. Two types of micro tubular cells with a different electrolyte thickness were characterized in this study. The size and layer thickness of tubular cells were summarized in Table 3. A large number of microtubes must be integrated to make cell bundles or stacks in order to increase cell surface area per unit volume, i.e., cell power per unit volume.

\subsection{Characterization of cell performance}

Fuel cell performance was measured as a function of operating temperatures for microtubular cell 2 as shown in Fig. 6. The open circuit voltage of the cell is around $0.95 \mathrm{~V}$ at $400^{\circ} \mathrm{C}$. It gradually decreased to $0.91 \mathrm{~V}$ at $550^{\circ} \mathrm{C}$ depending upon the

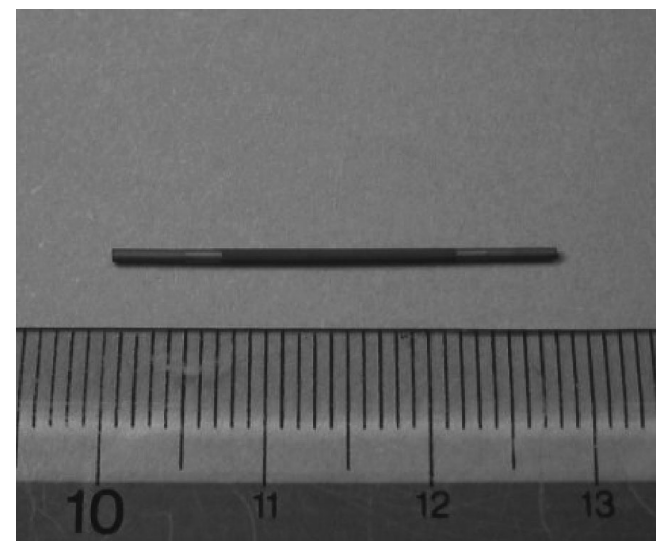

Fig. 5. Photograph of microtubular cell with an outer diameter of $0.96 \mathrm{~mm}$.

Table 3. Size and layer thickness of the prepared microtubular cells

\begin{tabular}{ccccccc}
\hline \multirow{2}{*}{$\begin{array}{c}\text { Tubular } \\
\text { cell }\end{array}$} & \multicolumn{2}{c}{ Diameter $(\mathrm{mm})$} & & \multicolumn{3}{c}{ Thickness $(\mu \mathrm{m})$} \\
\cline { 2 - 3 } \cline { 5 - 7 } \cline { 5 - 7 } Cell 1 & Outer & Inner & & Anode & Electrolyte & Cathode \\
\hline Cell 2 & 0.96 & 0.55 & & 125 & 53 & 22 \\
\hline
\end{tabular}

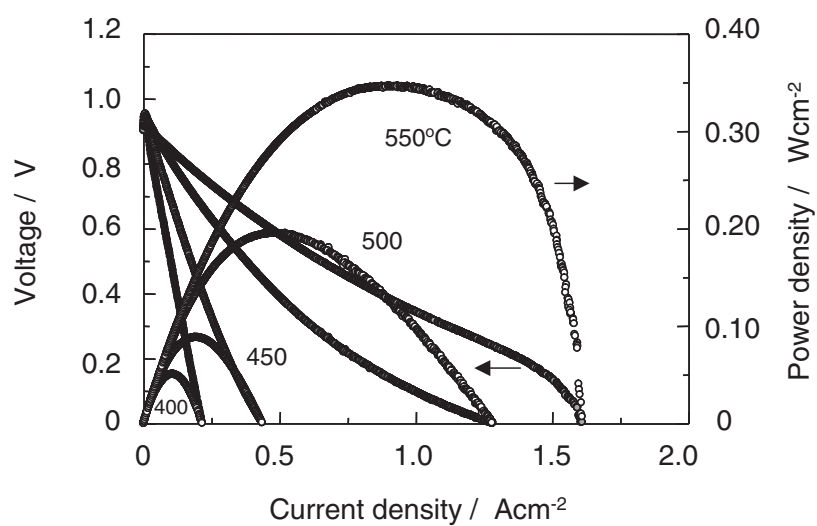

Fig. 6. Performance of microtubular cell 2 as a function of operating temperatures.

temperature. This relatively small OCV could be related to the electron conduction of the GDC electrolyte. The maximum power density of the cell reached $0.34 \mathrm{~W} / \mathrm{cm}^{2}$ at $550^{\circ} \mathrm{C}$ which is moderate in ordinal flat cells but is still smaller than the best value over $1.0 \mathrm{~W} / \mathrm{cm}^{2}$ for tubular cells. ${ }^{7), 13), 14)}$ In order to improve the cell performance, microstructure of the tubular cell should be controlled by considering the cell resistance. Impedance spectrum of the prepared cell shows that the ohmic resistance of the electrolyte and electrodes was $0.38 \mathrm{ohm} \mathrm{cm}^{2}$ and $1.02 \mathrm{ohm} \mathrm{cm}^{2}$ at $550^{\circ} \mathrm{C}$, respectively. In the present work we did not add any pore formers to obtain a more porous electrode structure which is known to effectively reduce the polarization of gas permeation. ${ }^{15)}$ Figure 7 shows the photomicrographs of the anode layer after the measurement of SOFC performance, suggesting a slightly porous microstructure, although it was not good enough for gas permeation. The porosity of this anode layer before and after reduction was confirmed to be $14 \%$ and $26 \%$, respectively. A series of work of Suzuki et al. clearly suggests that an anode layer with the porosity over $45 \%$ greatly reduces 


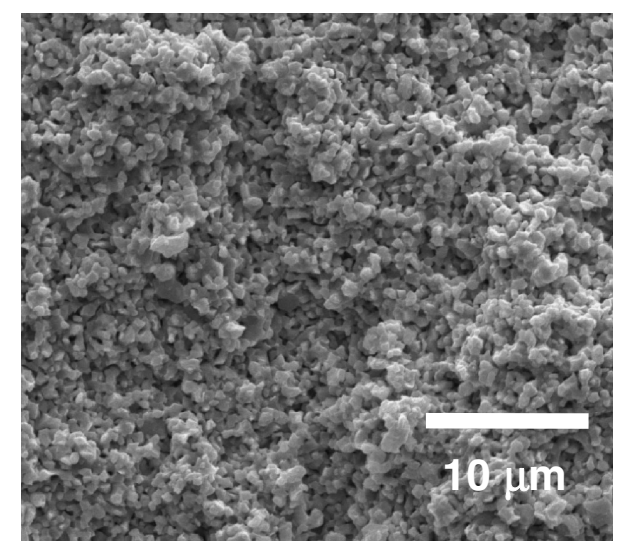

Fig. 7. Microstructure of anode layer in cell 2 after electric measurement.

the polarization for gas permeation. Furthermore, reduction of electrolyte thickness is also important to increase power density. ${ }^{16)}$ We are now studying microstructure control for the improvement of cell performance without loss of mechanical reliability.

\section{Conclusions}

Preparation of microtubular cells by the multi-dip coating was investigated. Homogeneous coating layer was formed by controlling the viscosity of the applied slurries and ceramic contents. Pre-coating of polystyrene on steel wire is useful to make a straight tube without requiring a large force for separation. This process affords a reliable and automated way to make a large number of cells. The prepared cells show moderate cell performance but are not good enough to make a high power generation unit by stacking. Further improvement could be achieved by the precise control of the cell microstructure and the electrode thickness.
Acknowledgement The authors acknowledge Anan Kasei Co. Ltd. for supplying the GDC powder. This work had been supported by NEDO, as part of the Advanced Ceramic Reactor Project.

\section{References}

1) P. Singh and N. Q. Minh, Int. J. Appl. Ceram. Technol., 1, 5-15 (2004).

2) A. Brisse, J. Schefold and M. Zahid, Int. J. Hydrogen Energy, 33, 5375-5382 (2008).

3) K. Hamamoto, Y. Fujishiro and M. Awano, J. Electrochem. Soc., 154, F172-F175 (2007).

4) W. J. Dollard, J. Power Sources, 37, 133-139 (1992)

5) K. Kendall and M. Palin, J. Power Sources, 71, 268-270 (1998).

6) A. Kawakami, S. Matsuoka, N. Watanabe, T. Saito, A. Ueno, T. Ishohara, N. Sakai and H. Yokokawa, "Advances in Solid Oxide Fuel Cell II," Ed. by N. P. Bansal, John Wiley \& Sons Inc. (2008) pp. 3-13.

7) T. Suzuki, T. Yamaguchi, Y. Fujishiro and M. Awano, J. Power Sources, 160, 73-77 (2006).

8) Y. Funahashi, T. Shimamori, T. Suzuki, Y. Fujishirto and M. Awano, J. Power Sources, 163, 731-736 (2007).

9) K. Kikuta, C. Kubota, Y. Takeuchi, Y. Ito and T. Usui, J. Eur. Ceram. Soc., 30, 927-931 (2010)

10) S. C. Singhal and K. Kendall, "High Temperature Solid Oxide Fuel Cells,” Elsevier Ltd. (2003).

11) Y. Liu, S.-I. Hashimoto, H. Nishino, K. Takei, M. Mori, T. Suzuki and Y. Funahashi, J. Power Sources, 174, 95-102 (2007).

12) T. Yamaguchi, S. Shimizu, T. Suzuki, Y. Fujishiro and M. Awano, J. Electrochem. Soc., 155, B1141-B1144 (2008).

13) T. Suzuki, Y. Funahashi, T. Yamaguchi, Y. Fujishiro and M. Awano, Fuel Cells (Weinheim, Ger.), DOI: 10.1002/fuce. 200800047.

14) B. C. H. Steele, Solid State Ionics, 129, 95-110 (2000).

15) S. P. Yoon, S. W. Nam, J. Han, T.-H. Liu, S.-A. Hong and S.-H. Hyun, Solid State Ionics, 166, 1-11 (2004).

16) T. Suzuki, Z. Hasan, Y. Funahashi, T. Yamaguchi, Y. Fujishiro and M. Awano, Science, 325, 852-855 (2009). 